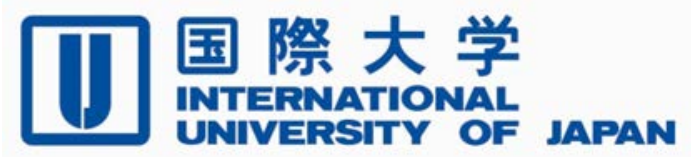

Economics \& Management Series

EMS-2014-13

\title{
Should E-government Be Transformational and Par- ticipatory? An Essay on E-government in the Utili- tarian Mode of Information Technology Use
}

Hun Myoung Park

The International University of Japan

November 2014

IUJ Research Institute

International University of Japan

These working papers are preliminary research documents published by the IUJ research institute. To facilitate prompt distribution, they have not been formally reviewed and edited. They are circulated in order to stimulate discussion and critical comment and may be revised. The views and interpretations expressed in these papers are those of the author(s). It is expected that the working papers will be published in some other form. 


\title{
Should E-government Be Transformational and Participatory? An Essay on E-government in the Utilitarian Mode of Information Technology Use
}

\author{
August 2014 \\ Hun Myoung Park, Ph.D., Associate Professor \\ Public Management and Policy Analysis Program \\ Graduate School of International Relations \\ International University of Japan
}

\begin{abstract}
This paper asserts that e-government works, in principle, in the utilitarian mode of information technology use rather than solidary and participatory modes. E-government stakeholders visit government Web sites to pursue material incentives and rarely expect interactions and edemocracy there although senior/executive managers tout transformational and participatory egovernment symbolically and/or ostensibly for their political gain. The notion of transformational e-government is almost rhetoric and has a reversed causal relationship that egovernment reforms government. Government reflects or shapes e-government. Due to the administrative neutrality, e-democracy is not likely or its effect will not be significant. Participation in the policy processes will be plausible when motivated and qualified users and civil servants/managers are available. In general, e-government itself is not transformational and participatory, but rather instrumental to get utilitarian incentives.
\end{abstract}




\section{Introduction}

Baum and Di Maio (2000) propose the first e-government model that has served as a prototype of other e-government stage models. The presence phase is the simplest level, where basic information is provided on government Web sites. Citizens in the interaction phase are able to search information, download documents, and email to government officials. Transaction moves forward to make entire transactions available online. The most advanced transformation phase redefines service delivery and reshapes the relationship between governments and citizens. As a phase goes up from presence to transformation, complexity, time, cost, and legal protection requirement also increase.

The United Nations Public Administration Network and American Society for Public Administration (Ronaghan, 2002, pp. 8-14) suggest five stages of e-government development on the basis of content and specific features available. In the emerging presence, a formal but limited Web provides static information, contact information, and FAQs, while enhanced presence makes available dynamic information, publications, newsletters, search, and e-mail addresses. Emerging and enhanced presences are similar to Baum and Di Maio’s presence phrase. Interactive presence supports formal interactions through e-mail and comment posting, database search, and downloading forms and application, whereas transactional stage provides complete and secure online payment. The final seamless and fully integrated presence provides all online information and services through a single entry point (portal) as a "unified package” (pp, 14 and 20). United Nations (2003 p.13-14; 2008, 16) later replaces this last stage with networked (consultation and collective decision making) or connected presence that includes horizontal and vertical connections, infrastructure connection, connections between governments and citizens, and connections among stakeholders. Similarly, Hiller and Bélanger (2001, pp. 175-176) suggest 
five stages of information (dissemination), two-way communication, transaction, integration (portal), and (political) participation. In West (2005) begins with the (highway) billboard stage, moves to partial service-delivery, and (one-stop) portal stage with fully executable and integrated service delivery, and then eventually reaches interactive democracy with public outreach and accountability measures (p.8-9).

These existing e-government models predict linear, stepwise, and progressive development of e-government so that e-government begins with a basic stage (e.g., Web presence and cataloguing) and moves stepwise through each higher stage one by one (Coursey \& Norris, 2008, pp. 524-525). These models implicitly suggests that a higher stage is better than its lower one with a motto of "more technology is better" until reaching the transformational "egovernment nirvana” (pp. 523 \& 525). Coursey and Norris (2008) conclude that existing egovernment models are just normative and speculative "guesswork" that was created in a vacuum (pp. 532-533).

Norris and Reddick (2013) analyze survey data of American local e-government in 2004 and 2011 and conclude that e-government has developed slowly and incrementally rather than has led to government transformation. They argue that the discrepancy between cyber-optimists' prediction and empirical evidence results from (1) e-government models were not grounded on relevant prior studies on information technology and government, but were developed in a vacuum; (2) cyber-utopianism itself is technological determinism; and (3) public administration by its nature is incremental. Therefore, "e-government remains almost primarily about delivering services and information along with some transactions and interactions. E-government remains also a mostly one-way activity from governments outward” (Norris and Reddick (2013, p. 174). 
Then why hasn’t e-government been transformational? Why has e-government been less likely to transform or reform government? Is e-government's destiny really incremental service delivery in one-way interaction mode? Shouldn't e-government be transformational and participatory? Why? In order to answer these questions, this paper challenges both cyber-utopian and cyber-dystopian views and suggests three modes of information technology use: utilitarian mode, solidary mode, and participatory mode. The next section summarizes various egovernment information and services in each stage before moving forward.

\section{Diversity of E-government Services}

Electronic government (e-government) refers to "[T]he use by governments of [W]ebbased Internet applications and other information technologies, combined with processes that implement these technologies, to enhance the access to and delivery of government information and services to the public, other agencies, and other government entities or bring about improvements in government operations” (E-government Act of 2002). E-government provides online information and services to the general public or citizens (G2C or C2B), business sector (G2B or B2G), and government itself including employees of departments and agencies (G2G). Some e-government applications (e.g., tax filing) require membership or registration that is limited to qualified users for the sake of security and privacy. Others are widely open to the general public without requiring membership at the expense of collective action problem like flaming on online forums.

Existing e-government models, despite some inconsistencies across models, are summarized in information, interaction, transaction, integration, and transformation and participation although the final stage is dropped in Table 1. See Hiller and Bélanger (2001, pp. 177) and Coursey and Norris (2008, p. 524) as well. The first information presence stage 
provides static information of events, agendas, codes, ordinances, regulations, FAQs, or allows citizens to download various forms, documents, video/audio clips. Citizens visit government Web sites to get contact information of civil servants in charge and search inside contents. This stage needs basic Web technologies and browsing and has no substantial difference among G2C, G2B, and G2G in this stage.

The interaction stage allows visitors to submit applications, search databases, and get other dynamic information like GIS maps. Citizens can communicate with civil servants in charge through email, chat, bulletin board (message board). Again there is no big difference among G2C, G2B, and G2G in this interaction stage.

The transaction stage often involves financial transaction as in filing various taxes and paying utility, fee, and fine. Citizens can register and renew licenses and properties (e.g., auto vehicle registration) and cast a ballot online (i.e., e-voting). E-procurement is an exemplary G2B application. Government employees may purchase items and arrange travel (reservation) through G2G (intranet in government), which is evolved from traditional government information systems before Web becomes pervasive. Government manages paychecks and other financial transactions. However, paychecks provided in PDF and financial records extracted databases are provided in information and interaction stages respectively. This stage needs more sophisticated technologies (e.g., public key infrastructure) than information and interaction stages to ensure security and privacy.

Table 1. Online public information and services of each stage of e-government

\begin{tabular}{lllll}
\hline & Information & Interaction & Transaction & Integration \\
\hline G2C & - Events \& agendas & - Submitting applications & - Paying tax, utility, fee, fine & - Government \\
& - Codes \& ordinances & - Searching databases & - Registration \& renewal & portal \\
& - Downloading forms \& audio/ & - GIS related services & - E-voting & - Intranet \\
\hline G2B & video clips (streams) & - Communicating with officials & - E-procurement & \\
\hline G2G & - Contact information & (Chat, email, bulletin board) & - Paycheck & - Purchase \& travel \\
& - Search/FAQs & & & \\
\hline
\end{tabular}


The integration stage is by and large one-stop government portal that integrates across departments, agencies, and all levels of government, or intranet used exclusively within government (Ronaghan, 2002; West, 2005). Layne \& Lee (2001) suggest vertical and horizontal integration stages as higher phases of e-government development to provide one-stop shopping for citizens. This stage does not say particular online information and services.

The final stage is of transformation, participation, and/or e-democracy. But these concepts oftentimes are not clearly defined. Cyber-optimists assert that e-government "would transform governments themselves, would fundamentally transform relations between governments and the governed, and ultimately, would produce electronic democracy" (Norris and Reddick, 2013, p.165). As described in reform propositions 1 and 2 of Kraemer and King (2006), information technology is expected to change organizational structures and thus reform public administrations.

However, transformation and participation stage cannot be juxtaposed with information presence, interaction, transaction, and integration stages on the same continuum. This final stage of e-government does not measure the progress of e-government services and the level of technical sophistication, but is rather used to indicate desirability or level of revolution in most egovernment research; transformational e-government is equivalent to great one. However, the transformation or participation stage is not on the same dimension where information-integration stages are located. For instance, e-mail and online forum are not only interactive but also participatory; these dimensions are not mutually exclusive. And transformation or revolution is relative to its baseline. An online service might be revolutionary in a society but not in others. Therefore, transformational or participatory e-government appears to be a just cyber-utopian 
hype and was mistakenly added to e-government stage models. It is at best a virtual image or mirage that has misled scholars and practitioners significantly.

These e-government models are criticized for being linear, stepwise, and progressive. Coursey and Norris (2008) put, “[T]hey are clearly at odds with the model's predictions that governments will move stepwise toward the adoption of more sophisticated e-government offerings, moving from information to transactions to integration and ultimately to transformation” (p. 532). However, this critiques is too much and harsh. Ronaghan (2002) forewarns, "This is not to suggest, however, that in order to achieve immediate success, a country must follow this linear path, ...” (p.11) and West (2005) also echoes, “This categorization does not mean all government websites go through these exact steps or that they undertake them in a linear order" (p. 9).

\section{Transformation, Reinforcement, and Normalization Theories}

There are three schools of thought in the roles of information technology (Norris, 2001, pp. 235-240; Park, 2007, pp. 25-28). Internet enthusiasts or cyber-optimists tout such positive effects of information technology such as transformation in government and society and participatory/deliberative democracy. Cyber-pessimists (Davis, 1999; Norris, 2001) argue that information technology reinforces current states and deepens the digital inequality between information haves and have-nots. Similarly, Kraemer and King (2006) conclude that information technology has been used to reinforce administrative and political arrangements rather than reform government administration. Both cyber-utopian and cyber-dystopian views are based on technological determinism that information technology influence society significantly, but posit positive and negative effects respectively. From the skeptical view, information technology does not necessarily change society significantly in either positive or negative way. Information 
technology instead reflects or is shaped by society. Margolis and Resnick (2000) claim "politics as usual” and Uslaner (2004) conclude that information technology is "not a threat to our society or its moral fiber” (p. 240). These optimism, pessimism, and skepticism are respectively summarized in transformation, reinforcement, and normalization hypotheses. Why do we have these contradictory theories?

DiMaggio, Hargittai, Neuman, and Robinson (2001) review Internet’s social effects in five research domains such as digital inequality, social capital, and political participation, and argue that the Internet's impact depends on "how economic actors, government regulation, and users collectively organize the evolving Internet technology” (p. 310). Verba, Schlozman, and Brady (1995) differentiate political activities along three dimensions of capacity for conveying

information, the volume of an activity (exerting pressure), and required resources such as money, time, and skills (pp. 43-48) and, in the similar vein, Weissberg (2005) argues that existing research on political participation focuses largely on electoral and familiar activities and thus fails to capture the variety of political participation and activism. In an effort to reconcile the contradictory hypotheses, Park (2007) acknowledges the diversity of civic engagement and argues that e-government and campaign Web sites operate respectively in the economy and solidarity models with different effects depending on the type of engagement. Similarly, Park and Perry (2008) show that the impact of political campaign Web sites varies according to the type of engagement.

These studies suggest that information technology use needs to be distinguished somehow in order to investigate its impact on society effectively.

\section{Who Uses? Why and How?}


We may ask such basic questions as "Who uses information technology services?” "Why do they use these services?" and "How do they use them?” to characterize the use of information technology services. Let us begin with purposes of and incentives to use information technology services.

\subsection{Why? Purposes and Incentives}

What are the purposes of information technology services and what are driving forces (incentives) to use? Clark and Wilson (1961) distinguish three incentive categories in an organization (pp. 134-137). Material incentives are tangible rewards that have monetary values. Both solidary and purposive incentives are intangible rewards without monetary values. Solidary incentives such as socializing, congeniality, sense of membership, maintenance of social distinctions are independent of or loosely coupled with the stated goals of organizations (pp. 134-135). Despite their material incentives, even commercial companies rarely have a stated goal of earning money. Purposive incentives are inseparable from the stated ends of an organization (purposes) that tend to be superpersonal, normative, or socially desirable goals such as eradication of corruption and government reform (p. 135-136). While utilitarian and solidary incentives benefit members directly, purposive incentives do not since members participate to pursue public values or public goods, which outweigh low prestige, penalty and threat, cost and time, and other material and solidary disadvantages (p.136). However, the "purposive incentive" is not always positive but can be malevolent and antisocial no matter whether the stated ostensible goal is socially desirable (Putnam, 2000, p. 21-22).

This study employs Clark and Wilson (1961) to modify Park (2007) and thus suggest utilitarian or material, solidarity, and participatory modes of information technology use. The utilitarian mode is based on efficiency, while solidary and participatory modes on volunteerism. 
Material rewards are driving forces of economic transaction and service delivery. The solidary mode pursues mutual benefit of members and mobilization of members and/or supporters. Finally, participatory or self-empowered mode is grounded on the purposive incentive that is tightly coupled with participation itself and self-fulfillment of participants.

\subsection{Who Uses Information Technology?}

We may consider three groups of information technology. The first group embraces consumers or clients, employees in firms and governments, and the general public. These users are inclusive (unrestrictive) but less committed to information technology services. Of course, customers, citizens, public servants, and executive and elected managers have their own interests in transaction. The second type consists of supporters, major parties, associations, and likeminded groups (e.g., races, hobbies, and diseases) who tend to pursue mutual benefit and mobilization. The final type of users includes activists, minor parties, issue-based groups, and advocacy who tend to have purposive incentive and be highly committed to their purposes.

\subsection{How? Activity and Interaction}

The use of information technology services is either an individual activity or collective action. Purchasing goods and filing income tax filing online are undertaken by an individual alone, whereas online forum and social network media are jointly used. Rheingold (2002) illustrates how "smart mobs" utilizes the information technology and overcomes the collective action problem to cooperate effectively with each other (pp. 56-61).

E-government applications may be grouped into information provision, interactions, and transaction depending on information flow (Park 2007: 36). Information provision is a one-way information flow from the service provider to customers, while information in transaction flows in the opposite direction (e.g., auto vehicle registration). Interactive services such as online 
forums and live chat provide a two-way communication channel. As technology progresses, however, various online information and services tend to be provided as an integrated package like social network media (e.g., facebook), blurring the lines between one technology and the others.

Stromer-Galley (2000) distinguishes computer-mediated human interaction from media interaction. The former is the "prolonged interaction between two or more people through the channel of a computer network,” while the latter occurs between users and the medium itself (pp. 117-118). Computer mediated human interaction occurs in two-way communication channels such as online forums, chat rooms, and e-mail. Online radios and chat rooms are real-time twoway human interaction tools that are constrained by time. Two-way human interactions often depend upon the attitudes of the two parties involved. If one party (e.g., government) "narrowcast" and other parties (e.g., general public) remain passive, this interaction is virtually one-way. By contrast, media interaction includes surfing the Web through hyperlinks, downloading various files, filing taxes, placing orders online, listening to music, watching video clips, and playing games. Online fundraising and poll are media interaction as well as one-way transaction.

Table 2. Mode of information technology use

\begin{tabular}{llll}
\hline & Utilitarian mode & Solidary mode & Participatory mode \\
\hline View & Normalization & Reinforcement & Transformation \\
& Skepticism & Pessimism & Optimism \\
\hline Purposes & Transaction, service delivery & Mutual benefit, mobilization & Participation, self-fulfillment \\
Incentives & Material rewards, efficiency & Solidarity & Self-empowerment \\
Tided to goal & Not tided & Flexible and loosely coupled & Not flexible, but tightly coupled \\
\hline Users & Customers, general public & Supporters, like-minded groups & Activists, minor parties, advocacy \\
Commitment & Low & Medium & High \\
\hline Activity & Individual transaction & Individual/collective action & Collective action, self-governing \\
Interaction & One-way, media interaction & One-way, media interaction & Two-way, human interaction \\
\hline Source: Modified from Park (2007) & &
\end{tabular}




\section{Mode of Information Technology Use}

This study elaborates Park's (2007) economy, solidarity, and action models of information and communication technology use and suggests three modes of information technology use on the basis of discussions in section 4 (Table 2). ${ }^{1}$ These ideal modes are theoretically distinct but not always clear in practice. Also the utilitarian model is not necessarily worse than solidary and participatory counterparts. Success or failure of an IT application does not depend on mode of IT use itself, but on whether it provides right information and services in the right format to the right person in the right time at the right time.

\subsection{Utilitarian mode: Normalization}

The utilitarian mode of information technology services is based on material incentives to maximize benefits of and minimize costs of transaction (service delivery). Users include customers, employees in the public and private sectors, and the general public (citizens) and are marginally committed. Cost savings in information dissemination and transactions are the driving forces of information technology adoption in firms and governments. E-government portals provide online forums to discuss policy issues, but this public outreach is not a primary concern. The transaction is undertaken individually and involves primarily one-way and media interaction. This utilitarian mode of information technology use reflects the skepticism with the normalization hypothesis.

\subsection{Solidary mode: Reinforcement}

Solidary mode pursues mutual benefits (including feelings of belonging) of members and mobilization of supporters. Major parties and like-minded groups utilize information technology

\footnotetext{
${ }^{1}$ Brainard and Siplon (2004) identify two models of nonprofit organization roles: economic model and voluntary spirit model. Nonprofit organizations in the economic model relies on material incentive and pursues efficiency, whereas the voluntary spirit model is based on solidarity and volunteerism to pursues mutual support and community-based mobilization (pp. 437-442). Chadwick and May (2003) propose three models of the interaction between state and citizens in e-government: managerial, consultative, and participatory models.
} 
in this manner. Voluntary users tend to participate individually or collectively in closed or semiclosed homogeneous groups. Campaign Web sites of major parties target primarily party members and supporters rather than adversaries and independent voters in order for reinforcement, fundraising, and volunteering (Bimber and Davis, 2003). Users in this solidary mode are committed to some extent but tend to leave easily since they are less empowered and purposive. Like the utilitarian mode, solidary mode relies more on one-way and media interactions rather than two-way and human interactions.

\subsection{Participatory mode: Transformation}

The final participatory mode is best used by activists, minor parties, issue-based groups, and advocacy who are enthusiastically committed to archiving their purposes. Selfempowerment incentive is not flexible but tightly coupled with purposive and normative goals of participation and self-fulfillment, which drive empowered members to eagerly take part. Users in the participatory mode are not just customers or passive members, but rather service providers and managers. Self-sustaining and self-governing distinguish active participants from simple volunteers and supporters. The participatory model is transformational (getting citizens engaged) while the solidarity mode is reinforcing. Even if discouraged, tightly committed activists are less likely to give up and leave easily. Monetary incentives also appeal to even to self-empowered activists, but its impact is not as substantial as in the utilitarian and solidary modes.

This mode of information technology use appears especially promising for disenfranchised activists and issue-based interest groups in the information era (Bimber, 1998, 2003; Pickerill, 2004; Putnam 2000; Verba et al., 1995, p. 469;). Pickerill (2004) argues that small interest groups use information technology more effectively than well-established organizations. In particular, narrowcasting facilitates the fragmentation of interest-based group 
politics and a shift toward a more fluid, issue-based interest group politics (Bimber 1998; Verba et al., 1995, p. 469).

Hill and Sen (2000) report that PIJAR, the Center for Information and Reform Action Network that was established by student activists to resist President Suharto in Indonesia, used KdP-Net (Kabar dari-PIJAR Net), its online periodical, to disseminate messages effectively under the New Order government. Lin (2001) offers a Chinese case where the Falun Gong took advantage of the Internet for its religious movement in order to avoid governmental censorship.

\section{Who Uses E-government and Why?}

Then how can we classify e-government use into three modes of information technology use? Individual citizens (G2C) and companies (G2B), as customers, pursue primarily an efficient way to obtain information and services from e-government. It is almost obvious that saving money and time (effort) are the strong driving forces of these customers who want to renew their auto vehicle registration, file their income tax, or bid in an e-procurement system. If such egovernment applications are difficult to use, time consuming, and costly, then customers with economic and utilitarian incentives will not use them and visit a department or agency instead no matter what purpose or goals (e.g., openness, transparency, and anti-corruption) such egovernment applications have. This is a typical one-way and/or media interaction. Customers

don't want to e-mail civil servants or leave questions in a message board to complete transaction; such e-mail and posting themselves imply some problems (e.g., inconvenience, time consuming, higher effort) to be resolved in these online services.

Ordinary civil servants differ from senior/executive managers and politicians (elected officials) in their incentive structure. Like customers and employees in companies, most civil servants tend to have material incentives when serving clients (citizens) and perform their tasks 
within government (e.g., paycheck services, benefits services, and financial systems). If G2C and G2G applications are not easy to use and come with additional burdensome workload, they are not willing to use them even if required. Civil servants do care if e-government can save time and effort of doing their jobs, if it imposes additional burdens and increases labor intensity, and/or if e-government helps strengthen monitoring and infringes their privacy especially in G2G. Accordingly, two-way and human mediated interactions are not favored by general civil servants because they are burdensome in terms of workload and unexpected, uncontrollable troubles (e.g., “flaming” starting from simple complaints). Government employees do not appear to care much about purposes of online public services (e.g., transparent and responsiveness) although they unwillingly pretend to care.

Senior/executive managers and politicians (elected officials) have an incentive scheme that is different from what ordinary civil servants have. They may use some G2G applications but rarely use G2C applications to serve citizens. Managers’ incentive is also utilitarian incentive to pursue their managerial or political gains rather than tangible material rewards. They oftentimes emphasize transformation, government reform, e-democracy, and e-participation that cyber-optimists tout, but such noble purposes tend to be just rhetoric. Stromer-Galley (2000) argues that candidates avoid online interaction because (1) it is burdensome to busy candidates, (2) they don't want to lose control over contents and messages in chatting rooms (forums) and bulletin boards, (3) and they don't' want to lose ambiguity of their vision and motto (pp. 122127). Like political candidates, senior/executive managers simply pretend to favor two-way and computer-human mediated interaction but rarely involve such deliberative interaction. They urge citizens to make policy suggestions and comments, but a few of them actually take citizens' feedback into account seriously in practice. 
Therefore, the equilibrium in e-government is the utilitarian mode of information technology use. Not only citizens and companies, but most civil servants also do not want twoway and computer-human mediated interactions from which they can actually benefit. Most citizens and civil servants appear to ostensibly expect solidarity, transformation, and/or participation from e-government. They would rather want efficient service delivery and other material incentives. Despite their rhetoric for political gain, senior/executive managers, in fact, cannot benefit directly much from two-way deliberative interactions and thus want to avoid or minimize them.

\section{Why Transformational E-government?}

Existing e-government models do not describe clearly the final stage but simply list such fancy words as transformation, participatory or interactive democracy, e-participation, edemocracy, digital democracy, and so on. A transformational e-government is expected to "cause or permit the relationship between citizens and governments to fundamentally change in positive ways, generally producing much more citizen-centric and responsive government and thereby increasing citizen trust in government dramatically” (Coursey \& Norris, 2008, p.524) and “... transform governments themselves, ... fundamentally transform relations between governments and the governed, and ultimately, ... produce electronic democracy” (Norris \& Reddick 2013, p.165). Is this “e-government nirvana” (Coursey \& Norris, 2008, p. 525) distinct from previous stages? Can any e-government application in the information, interaction, or transaction stage never, ever be transformational and participatory? Why not?

Most e-government enthusiasts appear to believe consciously and unconsciously that transformational e-government is achievable and desirable. In general, transformation involves business process reengineering (BPR) that results in fundamental, radical, and revolutionary 
change in the way of doing business. Bellamy and Taylor (1998) argue, "[The rhetoric of business process reengineering is] suffused with the conviction that ICTs must be introduced so as to drive radical, institutional change” (p. 76). West (2005) puts, “[G]overnment officials emphasize a model of e-government based on service delivery as opposed to system transformation. The public sector is less apt to think of the Internet as a tool for fundamental institutional change than for the delivery of particular services to business and the middle class" (p.10). What is wrong with this service delivery e-government? Should e-government be really transformational?

If transformational e-government means actual government reform and reinvention, the causal direction is reversed. E-government itself is a tool that government uses for doing its business (delivering public information and services). A government is mirrored by its egovernment. An e-government does not transform structures, processes, and relationships within and among governments but reflects existing structures, processes, and relationships. A good egovernment mirrors a "reformed,” “transformed,” “participatory” government. Bellamy \& Taylor (1998) state, "If changes occur in the information itself, ... then that is because of shifts within institutional structures” (p. vii) and conclude, “[H]eroic scenarios for reinventing government through the application of ICTs are fundamentally misleading. The institutions of governance will mould and fashion revolutionary potential of ICTs into an evolutionary reality” (p. 170).

E-government is not an all-round "transformer" that automatically ensures reinvention, transparency, openness, accountability, responsiveness, and so on. Transformation in structure and system (as opposed to simple automatization or computerization) requires BPR during analysis and design stages, which is oftentimes a complicated and tough process due to its social 
and political natures. An innovative e-government is not likely without proper reengineering of business processes of all levels of governments and their cooperation (e.g., amending related laws and sharing information). West (2005) puts, "institutional arrangements, budget scarcity, group conflict, cultural norms, and prevailing patterns of social and political behavior, ... restricts the ability of technology to transform society and politics” (p. 6). Kraemer and King (2006) conclude that information technology has never transformed government administration (p.11). Transformation is an "input” of e-government rather than its "output."

If transformation means modernization of online information and services by applying sophisticated or cutting-edge technologies, this is "technological transformation" rather than "systemic and structural transformation.” E-government in this fashionable and technology driven approach (as opposed to functional and content driven one) is often endorsed especially by tech-savvies and technocrats (as opposed to general clients) who have plunged into such egovernment benchmark races. A proper technology is determined by task and technology fit, not by technical sophistication. For example, mobile payment application like M-PESA in Kenya is built on a basic mobile service (simple message service) but successfully serves "unbanked" communities where bank services are rarely available and mobile penetration is high (Huges \& Lonie, 2007). ${ }^{2}$ Simply cataloging static information about incoming election may be as valuable as renewing auto vehicle registration and paying taxes as long as these applications provide public services appropriately.

Sophisticated or cutting edge technologies are oftentimes cost-ineffective and less stable. They also require higher computing resources and limit access to information and services. Egovernment is not free but funded by tax, user fee, and/or other sources. It is reasonable to put

\footnotetext{
${ }^{2}$ M-PESA is not technologically transformational in developed countries but revolutionary in "unbanked" communities.
} 
more emphasis on widely used services than on ones that only a few want (e.g., instance messaging and video on demand). More important is stable and functional service delivery rather than trendy and stylish online services. Given various demographic profiles of citizens, public organizations have to minimize use of cutting edge technologies to make e-government more accessible to those who are old, have disabilities, and/or do not have high computing resources.

The fundamental question here is not how to develop a technologically sophisticated egovernment (application), but how e-government can satisfy clients (i.e., government employees and citizens) by assisting them to do their jobs efficiently and effectively. E-government needs to ask such questions as, "Are online information and services what citizens want to get (necessity)?” “Are we delivering right information and services (relevancy, completeness, accuracy, and reliability) to the right audience (target) at the right time (timeliness) and in the right format (simplicity and easiness)?” "Can citizens access and use the information and services in a reasonable manner (availability, accessibility, and usability)?" and "Are the technologies used in an online application cost-effective (e.g., security and efficiency)?”

Proponents tout e-government's potential for openness, transparency, accountability, responsiveness, and anti-corruption. However, these social values are, in fact, by-products or indirect consequences of use of information technology in the utilitarian mode. If an online public service is developed for the sake of accountability and anti-corruption but is difficult to use and impose unnecessary burden for users, the application will remain almost obsolete right after its spotlighted debut for senior/executive managers. All stakeholders have their own utilitarian incentives and do not care much for purposes except the initial period. Hence, there is nothing wrong in service delivery oriented e-government. This argument does not, however, necessarily overlook the importance of such social values as transparency and accountability. 


\section{Is Participatory E-government Likely?}

E-government models implicitly take it for granted that e-government, although not likely now, will reach e-participation and e-democracy eventually (Hiller \& Bélanger, 2001; West, 2005). The most common example of e-democracy is e-voting that enables citizens to register and cast a ballot online. E-voting itself is a transaction application. Does this transaction service have potential to get apolitical citizens engaged? Most constituents will to expect saving time and money to vote from e-voting rather than participatory and direct democracy. If e-voting is difficult to use and time consuming for some reasons, engaged constituents will visit a polling booth but apolitical citizens are not willing to cast their ballots at the expense of time and effort. Notification of the election day and related information is one-way communication in the information stage and simply solicits votes in an efficient way without influencing constituents significantly. These applications are examples of the final stage but just illustrate the utilitarian mode of e-government use. It is notable that the utilitarian mode is neither necessarily unsuccessful per se, nor inferior to solidary and participatory modes.

What if an online service (e.g., bulletin board, chat room, or facebook) in a government Web site allows citizens to post their political views or a message to support a candidate and blame his/her rival? What if an issue develops to destructive, hostile, and uncontrollable debate so called "flaming?” Is it plausible or acceptable that government or civil servants provide such service? And what if an incumbent president and mayor tend to post, if not paint, their promotional materials (e.g., event photos and video streams) heavily on the government as if egovernment is his/her own campaign Web site? Is this e-democracy likely and/or desirable? Probably not. An e-government is inevitably political during its design and development stages 
(de Vries 2008), but it should ensure administrative neutrality although it is difficult to draw a clear line of acceptability.

If e-participation means citizens’ participation in policy process and or “public outreach,” then it makes more sense than e-democracy. However, only a few citizens have proper ability (knowledge and skills), willingness, resources (time an money), and efficacy for deliberative activities. Forty four percent of American Internet users visit e-government to get data about government, while only 13 percent of them read the blog of a government agency or official and 2 percent follow government agency or official on Twitter with big educational gap (Smith, 2010, p. 26). Senior managers in general pretend to favor two-way communication and tell citizens to make policy suggestions but do not have strong incentives to take individual comments into account carefully in policy processes. Downloading video clips, reading blogs, receiving text messages, or following on social networking media does not appear to make significant difference in political participation. Nevertheless, it is likely to develop successful e-democracy services like "Wiki government” where qualified and motivated participants and public managers are available (Noveck, 2009).

\section{Conclusion: “E-government as Usual”}

This paper suggests three modes of information technology use and then asserts that citizens, firms, and public servants use e-government basically in the utilization mode where these stakeholders find their equilibrium or focal point. Despite rosy rhetoric of transformational

and participatory e-government, e-government is used largely by clients and public servants who are willing to take advantages of efficiency and material incentives. Information search, service delivery (transaction), one-way interaction, media interaction are commonly preferred. 
This argument does not, however, mean that e-government shouldn’t be transformational and/or participatory. Rather than e-government reforms government, government and stakeholders determines e-government. Oftentimes e-government simply reflects current level of government and users; good government, public servants, and citizens will have good egovernment. "E-government as usual” is neither necessarily transformational (utopian) nor reinforcing (dystopian). Depending on a leadership style and specific (Wiki-like) application, cyber-optimistic e-government may be likely, but a dominant portion of e-government remains utilitarian. Hence, it is not surprising to have empirical results that Coursey and Norris (2008) and Norris and Reddick (2013) report.

Major political parties and like-minded groups will use information technology in the solidary mode. They are targeting at their supporters and members regardless of their ambitious slogans and mottos. Finally, minor parties and issue-based activity groups with self-empowered incentives utilize information technology in the participatory mode.

A transformational or e-democratic e-government appears to be unlikely and just a misleading mirage. Transformation of existing e-government development models appears to mean "technological transformation, "which is neither efficient, nor desirable. E-government is not "transformer" but an administrative tool of providing public information and services online. A transformational or revolutionary e-government, if any, requires systemic and structural transformation of government in advance. We need to ask how to develop and use e-government properly rather than look for "e-government nirvana" that is transformational only in a technological sense. "The most important question is not what the Internet will do to us, but what we will do with it” (Putnam, 2000, p.180). 


\section{References}

Baum, C., and A. D. Maio. “Gartner's Four Phases of E-Government Model”. Gartner Group, Research Note. 2000.

Bellamy, C., and J. A. Taylor. Governing in the Information Age. Berkshire, U.K. Open University Press, 1998.

Bimber, B. “The Internet and Political Transformation: Populism, Community, and Accelerated Pluralism”. Polity, 31(1), 1998, pp. 133-160.

Bimber, B., and R. Davis. Campaigning Online: The Internet in U.S. Elections. New York, Oxford University Press, 2003.

Brainard, L. A., and P. D. Siplon. “Toward Nonprofit Organization Reform in the Voluntary Spirit: Lessons from the Internet”. Nonprofit and Voluntary Sector Quarterly, 33(3), 2004, pp. 435-457.

Clark, P. B., and J. Q. Wilson. "Incentive Systems: A Theory of Organizations". Administrative Science Quarterly, 6(2), 1961, pp. 129-166.

Chadwick, A, and C. May. "Interaction between States and Citizens in the Age of the Internet: 'e-Government’ in the United States, Britain, and the European Union”. Governance, 16(2), 2003, pp. 271-300.

Coursey, D., and D. F. Norris. "Models of E-government: Are They Correct? An Empirical Assessment”. Public Administration Review, 68(3). 2008, pp. 523-536.

Davis, R. The Web of Politics: The Internet's Impact on the American Political System. New York: Oxford University Press, 1999. 
de Vries, W. T. “A Review of the Political Nature of ICT in G2G Integration Based on 3 Cases from the geoICT Domain”. Proceedings of the 2008 International Conference on Digital Government Research, 2008, pp. 124-131.

DiMaggio, P., E. Hargittai, W. R. Neuman, and J. P. Robinson. "Social Implications of the Internet”. Annual Review of Sociology, 27(1), 2001, pp. 307-336.

Hill, D., and K. Sen. “The Internet in Indonesia's New Democracy”. In The Internet, Democracy, and Democratization, edited by Peter Ferdinand, pp. 119-136. London, UK, Frank Class, 2000.

Hiller, J. S., and F. Belanger. "Privacy Strategies for Electronic Government." In . E-government 2011, edited by Mark A. Abramson ad Grady E. Means, pp. 162-198. Arlington, VA: PricewaterhouseCoopers Endowment for the Business of Government, 2001.

Hughes, N., and S. Lonie. "M-PESA: Mobile Money for the "Unbanked" Turning Cellphones into 24-hour Tellers in Kenya”. Innovations: Technology, Governance, Globalization, 2 (1-2), 2007, pp. 63-81.

Kraemer, K., and J. L. King. "Information Technology and Administrative Reform: Will EGovernment Be Different?". International Journal of Electronic Government Research, 2 (1), 2006, pp. 1-20.

Layne, K., and J. Lee. "Developing Fully Functional E-government: A Four Stage Model". Government Information Quarterly, 18(2), (2001), pp. 122-136.

Lin, Nan. Social Capital: A Theory of Social Structure and Action. New York, Cambridge University Press, 2001.

Margolis, M., and D. Resnick. 2000. Politics as Usual: The Cyberspace "Revolution". Thousand Oaks, CA, Sage Publications, 2000. 
Norris, D. F. "E-Government 2020: Plus ça Change, Plus C'est La Meme Chose”. Public Administration Review, 70 (Special issue), 2010, pp. s180-s181.

Norris, D. F. and C. G. Reddick. "Local E-government in the United States: Transformation or Incremental Change?" Public Administration Review, 73(1), 2013, pp165-175.

Norris, P. Digital Divide: Civic Engagement, Information Poverty, and the Internet Worldwide. New York: Cambridge University Press, 2001.

Noveck, B. S. Wiki Government: How Technology Can Make Government Better, Democracy Stronger, and Citizens More Powerful. Washington, DC: Brookings Institution Press, 2009.

Park, H. M. How Does Information and Communication Technology Affect Civic Engagement? An Analysis Focusing on Electronic Government and Campaign Websites. Unpublished Ph.D. Dissertation, Indiana University, 2007.

Park, H. M., and J. L. Perry. "Do Campaign Websites Really Matter in Electoral Civic Engagement? Empirical Evidence from the 2004 Post-election Internet Tracking Survey". Social Science Computer Review, 26(2), 2008, pp. 190-212.

Pickerill, J. "Rethinking Political Participation: Experiments in Internet Activism in Australia and Britain". In Electronic Democracy: Mobilisation, Organisation and Participation Via New ICTs, edited by R.K. Gibson, A. Rommele, and S. J. Ward, pp.170-193. London and New York: Routledge, 2004.

Putnam, R. D. Bowling Alone: The Collapse and Revival of American Community. New York: Simon \&amp; Schuster, 2000.

Rheingold, H. Smart Mobs: The Next Social Revolution. Cambridge, MA, Basic Books, 2002. 
Ronaghan, Stephen A. 2002. Benchmarking e-government: A global perspective. New York: United Nations and American Society for Public Administration. http://unpan1.un.org/intradoc/groups/public/documents/un/unpan021547.pdf

Smith, A. 2010. Government online: Internet gives citizens new paths to government services and information. Pew Research Center. Retrieved from http://www.pewinternet.org/2010/04/27/government-online/

Stromer-Galley, J. “On-line Interaction and Why Candidates Avoid It”. Journal of Communication, 50(4), 2000, pp. 111-132.

United Nations. United Nations global e-government survey 2003. Department of Economic and Social Affairs. New York, 2003.

United Nations. 2008. UN e-government survey 2008: From e-government to connected governance. Department of Economic and Social Affairs. New York, 2008.

Uslaner, E. M. "Trust, Civic Engagement, and the Internet". Political Communication, 21(2), 2004, pp. 223-242.

Verba, S., K. Schlozman, and H. E. Brady. Voice and Equality: Civic Voluntarism in American Politics. Cambridge, MA: Harvard University Press, 1995.

Weissberg, R. The Limits of Civic Activism: Cautionary Tales on the Use of Politics. New Brunswick, NJ: Transaction Publishers, 2005.

West, D. M. Digital Government: Technology and Public Sector Performance. Princeton, NJ: Princeton University Press, 2005. 